\title{
P1009
}

\section{臭素化ダイオキシンによるラットの単回経口投与毒性 一全身症状と造血系への影響一}

\author{
山本 静護、長野 嘉介、妹尾 英樹、竹内 哲也、松本 道治、大林 久雄、 \\ 野口忠、山崎 一法、有藤平八郎、松島泰次郎 \\ 中災防 日本バイオアッセイ研究センター
}

\section{【目的】}

本研究は、臭素化ダイオキシンの毒性を明らか にすることを目的として、臭素化ダイオキシンの 単回経口投与によるラットの全身状態と造血系へ の影響について検討した。

\section{【材料抢よび方法】}

6 週齢の 雌 雄 Crj：Wistar ラットに 2,3,7,8Tetrabromodibenzo- $p$-dioxin（以下 TBDD）を コーン油に溶解し、0(コーン油のみ投与)、10,30, $100,300 \mu \mathrm{g} / \mathrm{kgBW}$ の用量で単回強制経口投与 し、各群とも投与後 2 日、7 日及び 36 日に 5 匹の 動物を解剖した。観察期間を通して動物の一般状 態の観察、体重測定、また、各解剖日に血液学的パ ラメー夕、胸腺、脾臓の臓器重量の測定、骨髄、胸 腺、脾臓の病理組織学的検査、脂肪中 TBDD 濃度 の測定を実施した。

\section{【結果】}

TBDD の単回経口投与により、36 日の観察期間 中、雄の死亡はみられなかった。雌 $300 \mu \mathrm{g} / \mathrm{kg}$ 群 の 3 匹が 21, 23, 27 日に死亡し、それらの動物には 著しい体重減少、自発運動量の減少や削瘦などが みられた。また、脳のくも膜下や奉骾の出血もみら れた。生存動物では、雄 $300 \mu \mathrm{g} / \mathrm{kg}$ 群で 7 日と 36 日に、雌 $300 \mu \mathrm{g} / \mathrm{kg}$ 群で 7 日に、また、雌 $30 \mu \mathrm{g} /$ $\mathrm{kg}$ 以上の群で 36 日に体重増加の抑制がみられ た。

血液学的パラメータでは、TBDD 投与後 36 日 で雌雄とも $30 \mu \mathrm{g} / \mathrm{kg}$ 以上の群で赤血球数、へモグ ロビン濃度、へマトクリット值の減少がみられ、網 赤血球の増加を伴っていた。血小板数が雌雄とも 7 日と 36 日に投与濃度に対応して減少した。また、 白血球の減少が 36 日に雌雄とも $30 \mu \mathrm{g} / \mathrm{kg}$ 以上 の群でみられた。

胸腺の絶対重量と相対重量の減少が 2 日では雄 $30 \mu \mathrm{g} / \mathrm{kg}$ と $300 \mu \mathrm{g} / \mathrm{kg}$ 群のみに、7日では雌雄 とも $30 \mu \mathrm{g} / \mathrm{kg}$ 以上の群で、36日に雌雄とも 100 $\mu \mathrm{g} / \mathrm{kg}$ 以上の群でみられた。脾臓の相対重量の増 加が雄 $100 \mu \mathrm{g} / \mathrm{kg}$ 以上の群のみにみられた。

病理組織学的変化は 2 日ではまったくみられな かった。7日では雌雄とも $300 \mu \mathrm{g} / \mathrm{kg}$ 群で骨䯣の 造血組織の減少がみられ、36日では雌雄とも $100 \mu \mathrm{g} / \mathrm{kg}$ 以上の群でより重度を増した。また、脾 臓の髄外造血が 36 日で雄 $100 \mu \mathrm{g} / \mathrm{kg}$ 以上の群、 雌 $300 \mu \mathrm{g} / \mathrm{kg}$ 群でみられ、この雌には白脾髄の萎 縮もみられた。さらに中等度の胸腺の萎縮が 7 日 に雌雄とも $100 \mu \mathrm{g} / \mathrm{kg}$ 以上の群でみられ、36日で は重度を増した。

各解剖期に測定した脂肪中の TBDD は 7 日に 最大值を示し、以降漸減したが、36日でも 7 日の 值を基準にして雌雄とも約 20〜30\% が残存して いた。脂肪組織からの排出半減期を、one compartment model を適用して算出すると、雄 $100 \mu \mathrm{g} / \mathrm{kg}$ と $300 \mu \mathrm{g} / \mathrm{kg}$ 群ではそれぞれ 12〜14 日、雌 100 $\mu \mathrm{g} / \mathrm{kg}$ と $300 \mu \mathrm{g} / \mathrm{kg}$ 群ではそれぞれ 16〜13 日で あった。

TBDD 投与による急性影響のみられる投与量 は 30〜 $100 \mu \mathrm{g} / \mathrm{kg}$ で、脂肪組織中濃度はそれぞれ 47〜125 $\mu \mathrm{gTBDD} / \mathrm{kg}$ であった。TBDDに曝露し たヒトのアクネがみられる体内曝露量は 35 年後 の血液脂肪中の濃度加半減期を $5 \sim 10$ 年と仮定 して算出すると $13 \sim 143 \mu \mathrm{g} / \mathrm{kg}$ と報告されて㧈 り、ラットで急性影響がみられる体内曝露量に近 似していた。

\section{【考察】}

TBDD の単回経口投与によりラットの体重の 著しい減少、胸腺の萎縮、自発運動量の減少など wasting syndrome がみられた。また、造血系への 影響もみられ、死亡動物の脳、脊髄の出血は直接的 な死因になるものと考えた。

本研究は、厚生労働科学研究費補助金により実 施した。 